\title{
TINJAUAN LINGKUNGAN DAN PENANGGULANGAN ABRASI PANTAI PADANG - SUMATERA BARAT
}

\author{
Bambang Istijono ${ }^{1}$
}

\begin{abstract}
ABSTRAK
Kawasan pesisir Padang merupakan daerah permukiman yang padat, salah satu kawasan andalan yang menjadi prioritas untuk dikembangkan oleh Pemerintah Daerah Sumatera Barat. Amukan gelombang Samudera Hindia di pesisir Padang $(17,90 \mathrm{~km})$ dengan arah selalu berubah mengikuti musim merupakan permasalahan. Sepanjang 13,50 km telah terabrasi dalam berbagai intensitas dengan pengikisan rata-rata 2,20 m setiap tahun sejak 1918. Abrasi merupakan erosi pantai yang diikuti dengan longsoran pada material masif tebing pantai. Bentuk pantai Padang relatif lurus, sebagian besar pantainya disusun oleh pasir, dibelakang pantai berupa dataran alluvial yang luas. Konsep dasar penanggulangan abrasi pantai Padang adalah meredam pengaruh energi gelombang laut dengan pemasangan batu diameter $0,50-1,50 \mathrm{~m}$ dan pasir pantai yang terancam stabilitasnya. Groin dengan material batu yang dipasang menjorok ke laut 15-25 m dengan interval $50 \mathrm{~m}$ dan tanggul pantai adalah bentuk proteksi pantai yang cukup berhasil. Tetapi teknik ini terkadang merusak estetika keindahan panorama alami pantai.
\end{abstract}

Kata kunci : gelombang, abrasi, penanggulangan, groin, tanggul pantai

\section{PENDAHULUAN}

Dengan jumlah pulau sekitar 17.508 dan garis pantai sepanjang $81.000 \mathrm{~km}$, Indonesia dikenal sebagai negara mega-biodiversity dalam hal keanekaragaman hayati, serta memiliki kawasan pantai yang sangat potensial untuk berbagai opsi pembangunan. Namun demikian dengan semakin meningkatnya pertumbuhan penduduk dan pesatnya kegiatan pembangunan di wilayah pantai, bagi berbagai peruntukan (pemukiman, perikanan, pelabuhan, obyek wisata dan lain-lain), maka tekanan ekologis terhadap ekosistem dan sumberdaya pantai dan laut itu semakin meningkat. Meningkatnya tekanan ini tentunya akan dapat mengancam keberadaan dan kelangsungan ekosistem dan sumberdaya pantai, laut dan pulau-pulau kecil yang ada di sekitarnya.

Kota Padang adalah salah satu kawasan andalan dalam pembangunan di Sumatera Barat yang terletak di kawasan Pantai Barat Sumatera memiliki penduduk lebih dari 830.000 jiwa (Gambar 1.1). Sebagai ibukota propinsi, pertumbuhan daerah pemukiman sangat pesat dan tidak merata yang ditandai lebih dari $70 \%$ warganya mendiami kawasan aliran sungai dan pantai. Ketimpangan dalam pertumbuhan kota tersebut diikuti oleh eksploitasi kawasan pantai yang dijadikan sebagai daerah pemukiman dan industri. Eksploitasi manusia menjadikan kawasan Pantai Padang sangat rentan terhadap kerusakan lingkungan.

Beberapa bentuk penanggulangan perubahan lingkungan dan bencana di kawasan Pantai Padang akibat abrasi, banjir, dan longsor yaitu dengan membuat tanggul pantai dan infastrukur lainnya.

\footnotetext{
${ }^{1}$ Staf Pengajar Jurusan Teknik Sipil Fakultas Teknik Universitas Andalas
} 
Penanggulangan abrasi pantai terutama bertujuan mempertahankan fungsi pantai sebagai tempat hidup biota pantai, sebagai wadah muara sungai, sebagai areal hunian nelayan dan obyek wisata. Dalam kaitan ini areal pantai yang kondisinya baik (normal) akan besar artinya bagi pelaksanaan RUTRK (Rencana Umum Tata Ruang Kota) dalam rangka mewujudkan peran Kota Padang secara optimal. Untuk wewujudkan hal tersebut di atas perlu dilakukan kajian yang lebih mendalam.

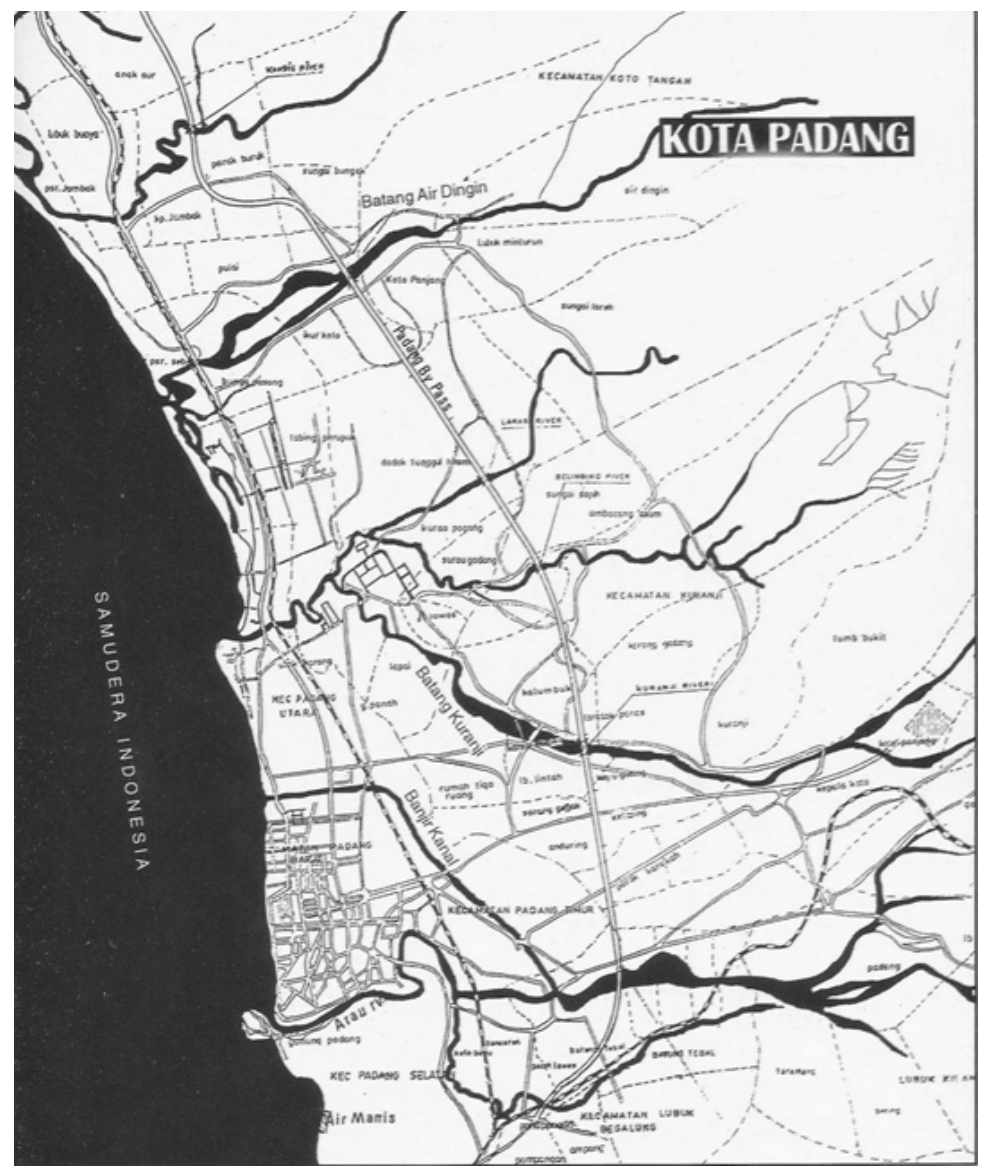

Gambar 1.1 Kota Padang dan Kawasan Pantai Padang

\section{METODA PENELITIAN}

Penyelidikan geologi merupakan tahapan yang paling utama dalam melakukan perencanaan dan pengolahan wilayah pantai, dimana dari penyelidikan tersebut dapat diperoleh berbagai informasi dan data potensi sebagai penunjang bahkan penentu dalam tahapan selanjutnya. Penyelidikan geologi berguna untuk menunjang pengelolaan dan pelestarian potensi lingkungan pantai dan perairan di sekitarnya di wilayah pantai Indonesia yang erat kaitannya dengan pengembangan kawasan secara terpadu dan mendukung pengelolaan wilayah di sektor perekonomian serta industri strategis dan kerekayasaan. Tujuan dari penyelidikan geologi di kawasan pantai adalah:

a. Memetakan garis pantai.

b. Memetakan kedalaman dasar laut, dimana akan dihasilkan peta titik-titik kedalaman dan peta batimetri.

c. Pemetaan kedalaman dasar laut dapat dilakukan dengan bantuan alat pemeruman (Echo Sounder) yang akan menghasilkan data berupa penampang seismik bawah laut. Penampang ini merupakan hasil rekaman gelombang pantul dari bidang-bidang pantul akibat adanya 
kontras densitas pada interface antara lapisan yang satu dengan yang lainnya. Sehingga dengan karakteristik dan konfigurasi refleksi yang muncul dan dikontrol dengan data geologi yang ada dapat ditafsirkan penampang geologi yang menggambarkan unsur-unsur seperti perlapisan, patahan, jenis litologi, ketebalan dan sebarannya.

d. Melakukan penyelidikan pasang surut untuk mengetahui tipe pasang surut dan sebagai koreksi hasil kedalaman dasar laut

e. Pasang surut (pasut) ialah proses naik turunnya muka laut yang hampir teratur, terutama dibangkitkan oleh gaya tarik bulan dan matahari. Karena posisi bulan dan matahari terhadap bumi selalu berubah secara hampir teratur, maka besarnya kisaran pasut juga berubah mengikuti perubahan posisi-posisi tersebut. Selain itu, pasut terdiri dari berbagai komponen yang dapat dikelompokkan menurut siklusnya, seperti komponen pasut harian (diurnal), tengah-harian (semi-diurnal), atau komponen perempat harian (quartanal). Komponen-komponen pasut tersebut menentukan tipe pasut di suatu perairan. Jika perairan tersebut mengalami satu kali pasang dan surut perhari, maka kawasan tersebut bertipe pasut tunggal. Jika terjadi dua kali pasang dan dua kali surut dalam satu hari, maka pasutnya dikatakan bertipe pasut ganda. Tipe pasut lainnya merupakan peralihan antara tipe tunggal dan ganda, dan dikenal sebagai pasut campuran. Tipe pasut ini dapat berubah tergantung terutama pada kondisi perubahan kedalaman perairan atau geomorfologi pantai setempat.

f. Menganalisa data arus laut dan angin permukaan untuk mengetahui gejala yang mungkin mempengaruhi perubahan bentuk, letak garis pantai dan untuk mengetahui banyaknya sedimen laut yang dapat diangkut setiap tahun.

g. Arus merupakan perpindahan massa air dari satu tempat ke tempat lain, yang disebabkan oleh faktor seperti gradien tekanan, hembusan angin, perbedaan densitas, atau pasang surut. Di sebagian besar perairan, faktor utama yang dapat menimbulkan arus yang relatif kuat adalah angin dan pasang surut. Arus yang disebabkan oleh angin pada umumnya bersifat musiman, dimana pada satu musim arus mengalir ke satu arah dengan tetap, dan pada musim berikutnya akan berubah arah sesuai dengan perubahan arah angin yang terjadi. Pasang surut di lain pihak menimbulkan arus yang bersifat harian, sesuai dengan kondisi pasang surut di perairan yang diamati. Pada saat air pasang arus pasut pada umumnya akan mengalir dari lautan lepas ke arah pantai, dan akan mengalir kembali ke arah semula pada saat air surut. Dengan mengetahui pola sirkulasi arus di suatu perairan yang diamati, seorang pengamat akan dengan mudah menentukan arah dan sebaran dari materi yang terkandung (dibawa) oleh air yang mengalir bersama arus tersebut.

h. Menganalisa data parameter gelombang.

i. Pada umumnya kondisi gelombang di suatu perairan diperoleh secara tidak langsung dari data angin yang terdapat di kawasan perairan tersebut. Hal ini didasarkan atas kondisi umum yang berlaku di laut, yaitu sebagian besar geolombang di laut dibentuk oleh energi yang ditimbulkan oleh tiupan angin. Gelombang jenis ini dikenal sebagai gelombang angin. Gelombang ini merupakan fungsi dari tiga fakta, yaitu kecepatan angin, lamanya angin berhembus (duration), jarak dari tiupan angin pada perairan terbuka.

j. Melakukan analisa sedimen laut dan mineral berat serta mempelajari proses sedimentasinya.

k. Sedimen perairan pantai dan laut di Indonesia terdiri dari berbagai tipe tergantung pada proses geologi. Proses tergerusnya pantai (abrasi) dan bertambah dangkalnya perairan pantai (sedimentasi, pengendapan) merupakan proses alami yang dapat terjadi di semua pantai. Jika terjadi proses abrasi di suatu kawasan pantai, maka sesuai dengan hukum keseimbangan, akan ada kawasan pantai di tempat lain yang bertambah. Kondisi sebaliknya juga berlaku. Seringkali kedua proses itu berlangsung secara berurutan, atau dengan kata lain, jika saat ini terjadi erosi di pantai A, dapat diharapkan suatu waktu di pantai tersebut akan terjadi proses pengendapan. Dengan demikian yang perlu dicermati adalah berapa lama waktu yang dibutuhkan dari adanya proses erosi hingga terjadi proses sedimentasi. Periode tersebut dapat berlangsung relatif cepat atau bahkan lama sekali. 
1. Memetakan situasi dan karakteristik garis pantai.

m. Menyelidiki sebaran fauna di sekitar pantai dan lepas pantai.

Metode penelitian dilakukan dengan kajian literatur penelitian terdahulu yang telah dilakukan oleh lembaga-lembaga terkait, kajian pustaka dan survey lapangan.

\section{PEMBAHASAN}

\subsection{Geologi dan Geomorfologi}

Kota Padang secara geologi tersusun oleh sebagian kecil oleh batugamping tua berumur Perm, terhablur ulang dengan sisipan tipis dari serpih, batupasir dan tuf. Batuan terobosan (intrusi) granit dan granodiorit berumur Miosen, batuan vulkanik tua berumur Oligo-Miosen yang terdiri atas lava bersusunan andesit - basal, breksi dan tuf, terubah dan termineralkan; sebagian besar disusun oleh batuan vulkanik Plio-Plistosen yang terdiri atas tuf breksi, dan lava yang bersusunan riolit, dasit, dan andesit, tuf padu, tuf hybrid, tuf sela dan tuf batugamping dengan breksi dan lava; dan endapan aluvial berupa endapan danau dan pantai (Gafoer dkk, 1996).

Pesisir Pantai Padang membentuk pantai lurus (long beach) dengan panjang pantai kurang lebih 7,5 $\mathrm{km}$. bentang alam bagian darat (coastal land) kawasan pantai ini berupa dataran aluvium berparas (relief) rendah. Bentuk pantainya di sekitar muara-muara sungai berupa spit pasir. Sedimen pantai yang menyusun kawasan pantai ini sebagian besar terdiri dari pasir pantai. Kerikil terutama terdapat di sekitar muara-muara sungai besar yang memperlihatkan adanya proses sedimentasi aktif. Pantai ini umumnya berenergi gelombang laut cukup tinggi $(>2 \mathrm{~m})$ terutama terjadi pada musim angin barat. Jenis pantai ini dapat juga dikelompokkan sebagai jenis pantai berenergi tinggi. Sedimentasi di kawasan pantai cukup tinggi yang disertai oleh abrasi cukup kuat. Arah arus sejajar pantai berarah Utara Selatan (Darlan, Yudi,2004)

\subsection{Iklim dan Batimetri}

Kawasan laut Kota Padang memiliki pola arus permukaan yang dipengaruhi oleh pola angin geostropik atau angin munson. Berdasarkan karakteristik iklim di belahan bumi selatan (southern hemisphere), maka kawasan sepanjang pantai Padang dipengaruhi oleh angin musim barat yang bertiup bulan November sampai Maret dan angin musim timur bertiup dari bulan Mei sampai September. Angin musim barat di perairan Kota Padang berkekuatan rata-rata 9 -10 knot bertiup ke arah tenggara hampir sejajar dengan garis pantai Padang. Arus permukaan berarah ke pantai pada saat air pasang, sedangkan pada saat air surut arus permukaan berarah ke laut barat dengan kecepatan lebih besar dibanding saat pasang. Siklus pasang surut di perairan Kota Padang adalah dua kali pasang dan dua kali surut dalam sehari.

Dasar laut perairan kota Padang memiliki pola kontur batimetri mengikuti morfologi daratan pantai. Kedalaman minimum terukur $1 \mathrm{~m}$ dan kedalaman maksimum $52 \mathrm{~m}$. Morfologi dasar laut dekat pantai (surf zone) berdasarkan kerapatan kontur batimetri menunjukkan adanya kemiringan pantai lebih curam dibandingkan daerah laut lepas (offshore). Tetapi secara umum kemiringan cukup berangsur turun (gradual) dengan derajat kemiringan kurang dari $1^{\circ}$. Dari bentuk morfologi dasar laut tersebut dan posisi garis patai yang terbuka dengan Samudera Hindia, maka morfologi ini sering menimbulkan gelombang pasang, yang cukup aktif dan membentuk zona-zona abrasi di sekitar pantai (Dep. Pekerjaan Umum,1995) 


\subsection{Tinjauan Lingkungan}

Jenis pantai yang terdapat di kawasan Pantai Padang hampir seluruhnya berupa pantai pasir serta membentuk pantai lurus (long beach). Panjang pantai seluruhnya kurang lebih 17,90 km. Bentang alam bagian darat (coastal land) kawasan pantai berupa dataran aluvium berelief rendah. Bentuk pantainya di sekitar muara-muara sungai berupa endapan sedimen pasir. Sedimen pantai yang menyusun kawasan pantai ini sebagian besar terdiri atas pasir pantai. Kerikil terutama terdapat di sekitar muara-muara sungai besar yang memperlihatkan adanya proses sedimentasi aktif. Pantai ini umumnya berenergi gelombang laut cukup tinggi $(>2 \mathrm{~m})$ terutama terjadi pada musim angin barat.

Hutan mangrove di kawasan perairan Kota Padang memiliki luas kurang lebih120 ha, terdapat di kawasan Sungai Pisang, Bungus Teluk Kabung, Koto Tangah, dan pulau-pulau di perairan Kota Padang dengan tingkat kerusakan $70 \%$. Jenis flora yang ditemukan pada hutan mangrove Kota Padang sebanyak 6 jenis mangrove sejati dan 1 jenis mangrove ikutan. Jenis tersebut adalah Sonneratia alba, Rhizophora apiculata, Bruguiera gymnorrhiza, Ceriops tagal, Xylocarpus granatum, Aegiceras corniculaum, dan Hibiscus tliaceus.

Luas areal terumbu karang di perairan kota Padang adalah 1.124,73 Ha (Darlan, Yudi dkk, 2004). Dengan karang hidup sebesar 51,89\% atau seluas 583,65 Ha. Rata-rata kondisi karang hidup ini termasuk kriteria rusak berat. Terumbu karang pada beberapa pulau-pulau di perairan kota Padang dalam kondisi rusak berat dengan persentase tutupan karang berkisar antara 7,80 - 25,59\%. Kondisi kerusakan disebabkan oleh terjadinya pemutihan koloni karang (bleaching) yang diikuti dengan kematian karang pada awal tahun 1998. Peristiwa ini dipengaruhi oleh perubahan suhu air laut. Sejak kejadian itu sampai saat ini telah terjadi pemulihan (recovering) melalui proses kolonisasi.

\subsection{Penanggulangan Abrasi}

Abrasi adalah proses tergerusnya pantai yang biasanya diikuti longsoran (runtuhan) pada materal masif, seperti tebing pantai (Gambar 3.2). Abrasi menyebabkan mundurnya posisi garis pantai dari kedudukan semula (ke arah darat). Abrasi umumnya diikuti oleh proses sedimentasi (pengendapan) yang merupakan suatu sistem keseimbangan pantai. Jika terjadi proses abrasi di suatu kawasan pantai, maka sesuai dengan hukum keseimbangan, akan ada kawasan pantai di tempat lain yang bertambah. Kondisi sebaliknya juga berlaku. Kegiatan abrasi dan sedimentasi akan berusaha mencapai stabilitas yaitu berupa geometri pantai yang stabil.

Kawasan Pantai Padang merupakan kawasan pantai abrasi. Berdasarkan penelitian dari Pusat Penelitian dan Pengembangan Geologi Kelautan Bandung, garis Pantai Padang mengalami kemunduran $6 \mathrm{~m} /$ tahun ke arah darat (Gambar 3.1). Sedangkan stabilitas untuk pembentukan geometri pantai stabil diperkirakan mencapai 40 meter ke arah pusat kota, di mana terdapat pemukiman padat penduduk, pertokoan, perkantoran serta berbagai fasilitas kota lainnya (Dinas PSDA Sumatera Barat, 1999). Upaya pengamanan pantai Padang telah dimulai tahun 1968 sedangkan kegiatan fisiknya dimulai pada tahun 1969 sampai sekarang. Konsep dasar penanggulangan yang dijalankan adalah meredam pengaruh energi gelombang laut dengan pemasangan batu dan pasir di pantai yang terancam stabilitasnya sehingga tercapai kelancaran arus sedimentasi di perairan pantai secara alami. Konsep ini diimplementasikan melalui pemasangan groin di setiap interval jarak 50 meter (diameter batu 0,50-1,50 m) dipasang menjorok ke laut 1525 m (Nikken Cons,2001), dan pelaksanaannya berlanjut sampai dengan tahun 2013. Pembuatan tanggul pantai adalah salah satu cara untuk menjaga pantai dari abrasi (Gambar 3.3, 3.4 dan 3.5). Groin (krib) yang telah terpasang sejumlah lebih dari 50 unit dengan volume batu terpasang lebih dari $172.000 \mathrm{~m} 3$ dan geotextile terpasang lebih dari $93.000 \mathrm{~m} 2$, sedangkan tanggul pantai terpasang sepanjang lebih dari $5.300 \mathrm{~m}$ dengan batu terpasang lebih dari $123.000 \mathrm{~m} 3$, dan dengan memanfaatkan batu gunung dari lokasi Gunung Sarik Padang. Hasil penanggulangan abrasi 
dengan pembangunan groin dan tanggul penahan pantai cukup berhasil menjaga garis pantai, tetapi teknik ini terkadang dianggap merusak keindahan panorama pantai.

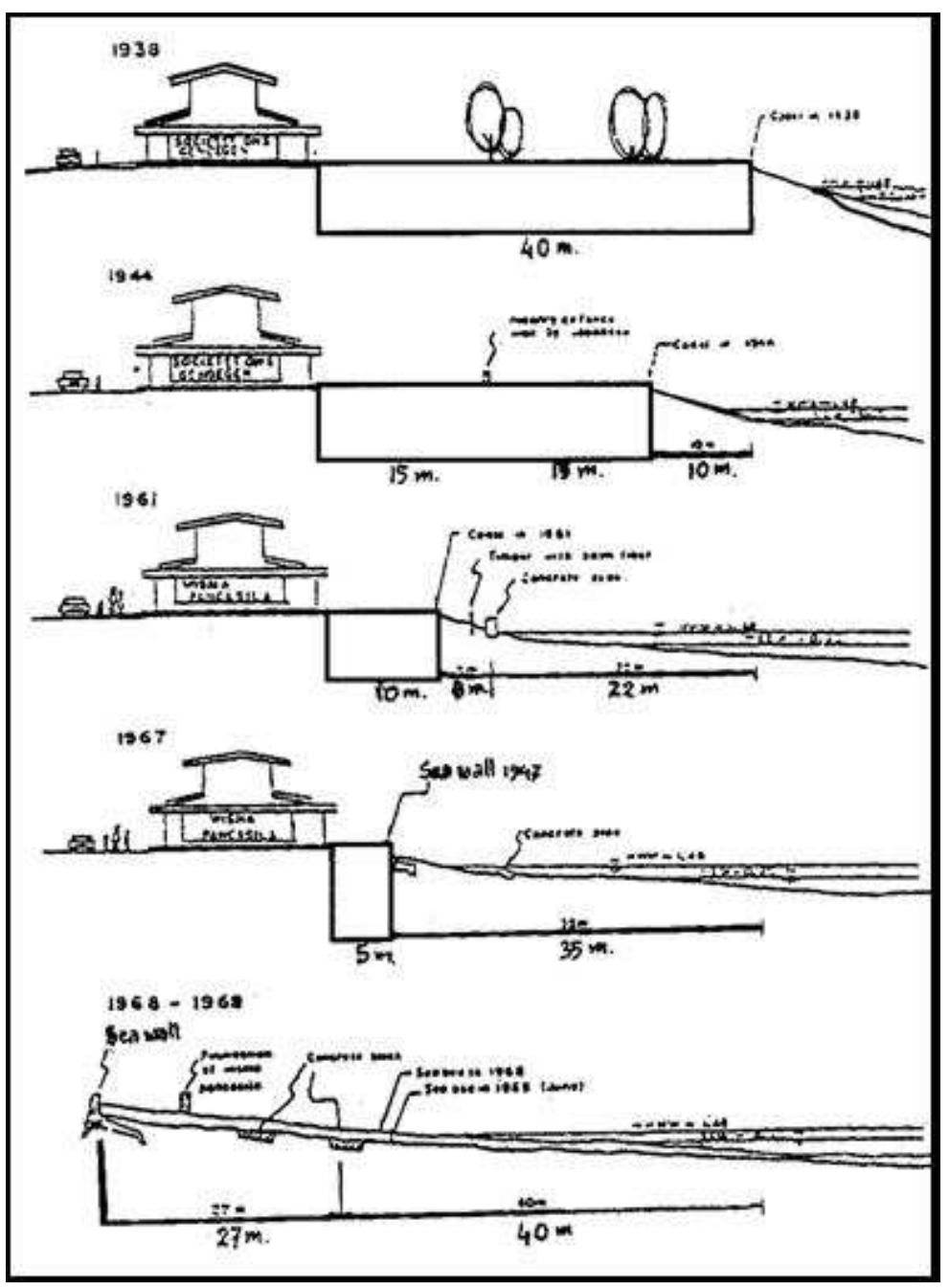

Gambar 3.1 Kronologis Penyusutan Pantai Kota Padang akibat abrasi tahun 1938 - 1969 ( Sumber : Dinas PSDA Sumatera Barat)

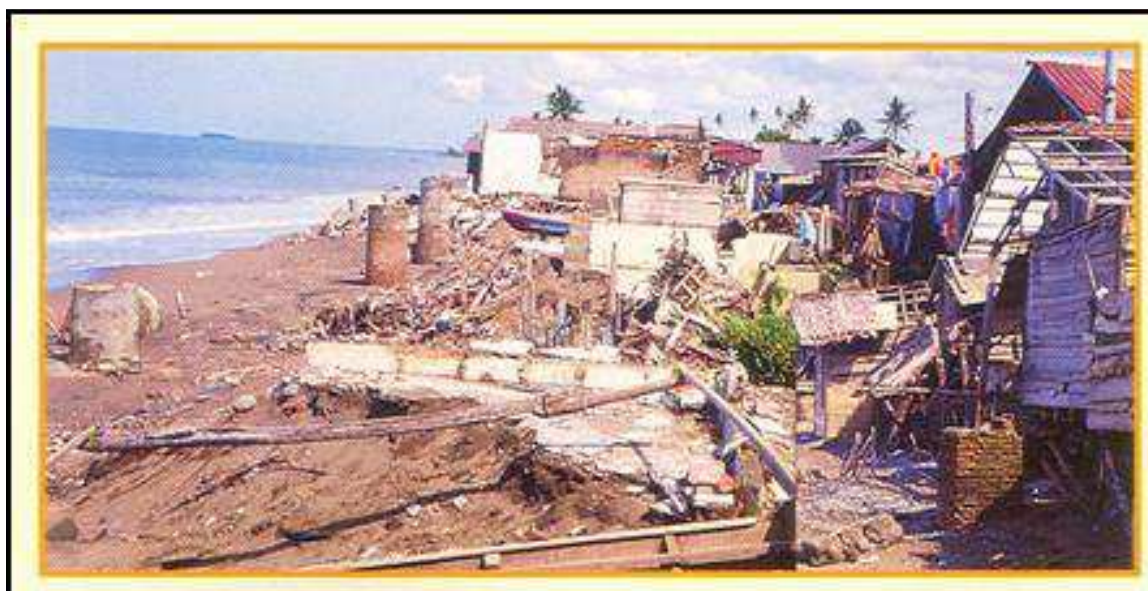

\section{Bagian}

pemukiman ofi Pantai Ujung

Karang yang

porak poranda

diteriang badai

lgoiombang laut

disertai angin

kencang) bulan

November 1998,

saat pantainya

beium tertindung

krib sama sekali.

Gambar 3.2 Kerusakan pantai di Ujung Karang, November 1998 


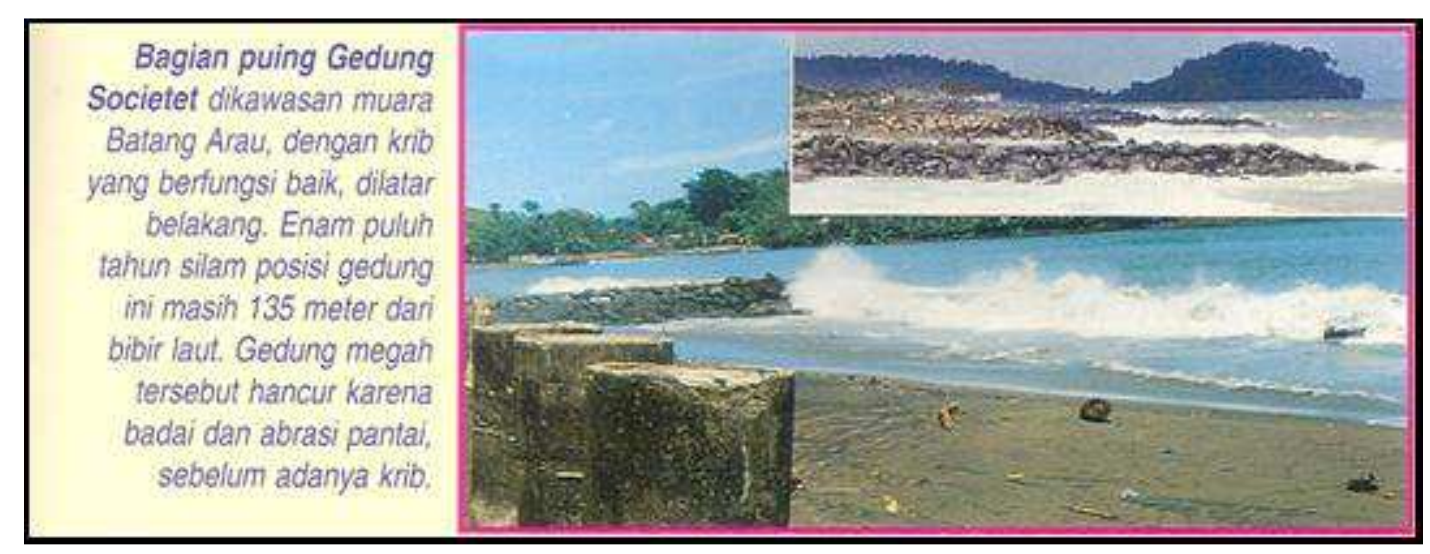

Gambar 3.3 Penanganan Abrasi di Muara Banjir Kanal

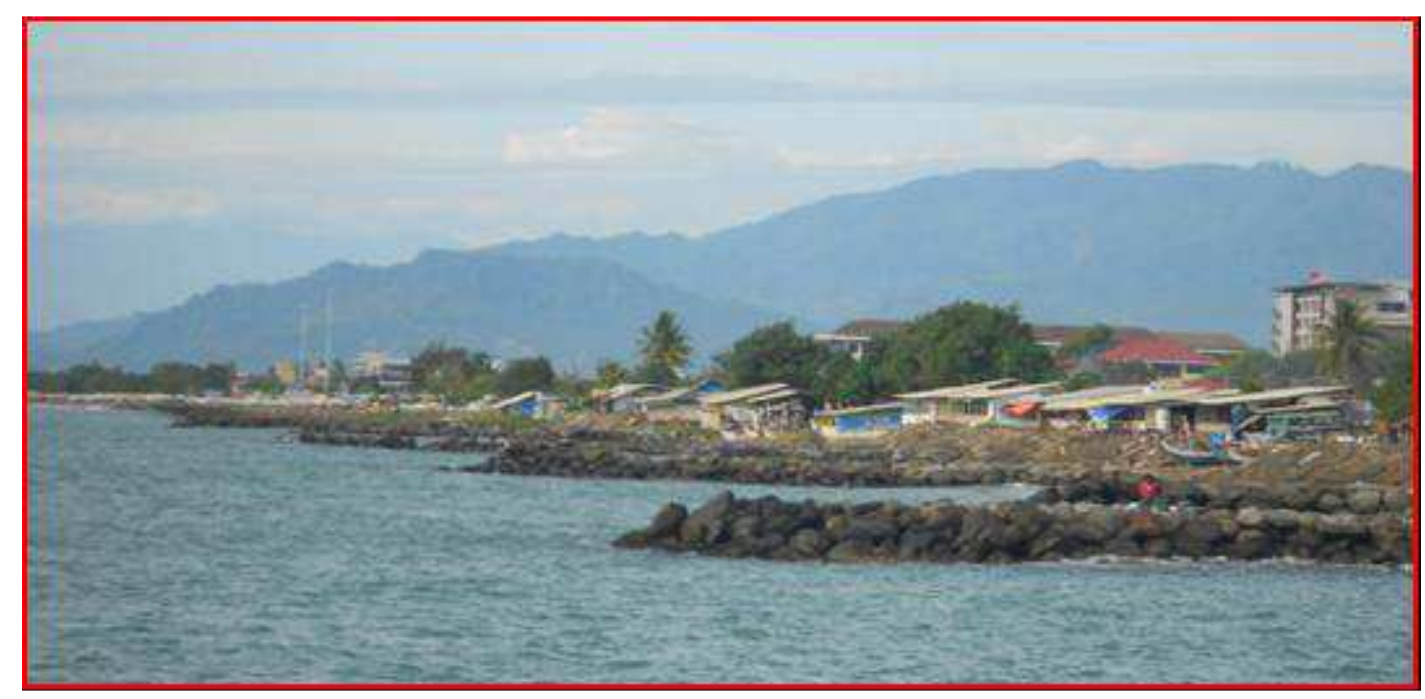

Gambar 3.4 Penanganan Abrasi di bagian kanan Muara Banjir Kanal

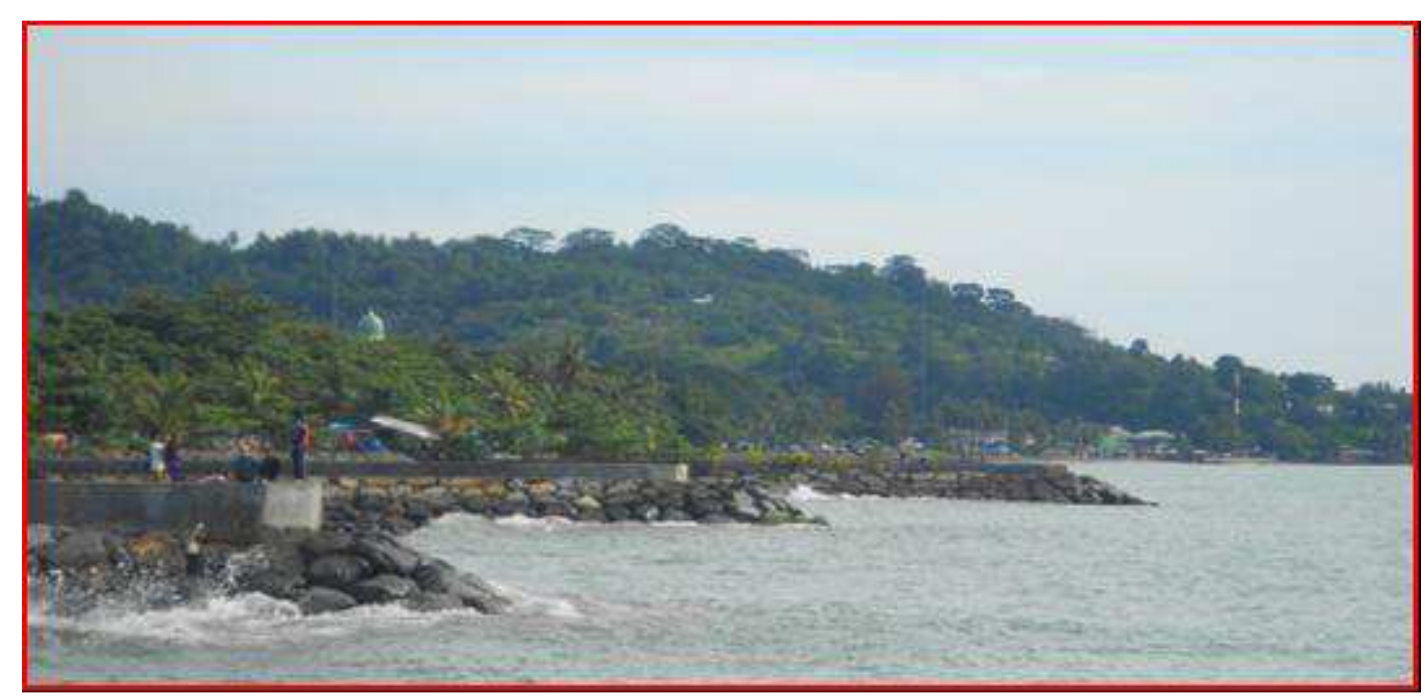

Gambar 3.5 Penanganan Abrasi di bagian kiri Muara Banjir Kanal 


\section{KESIMPULAN}

Kawasan Pantai Padang sebelumnya merupakan kawasan pantai abrasi, garis pantai mundur 6 $\mathrm{m} / \mathrm{tahun}$, bentuk pantai relatif lurus, sebagian besar pantainya disusun oleh pasir, di bagian belakang pantai berupa dataran aluvial yang luas. Terumbu karang dan hutan mangrove mengalami kerusakan berat sampai sangat berat. Aktivitas manusia di dalam pengembangan kawasan ini seringkali menimbulkan dampak bencana yang lebih buruk seperti penebangan hutan mangrove dan hutan lindung sehingga menimbulkan abrasi dan sedimentasi, longsor, dan banjir.

Daya tarik kawasan ini mempunyai potensi wisata pantai dan wisata bahari cukup baik. Gelombang pasang dan tsunami sewaktu-waktu bisa terjadi di sini. Tanggul-tanggul pantai adalah bentuk proteksi pantai kawasan ini dari abrasi. Teknik ini terkadang merusak estetika keindahan panorama alami pantai.

Penanggulangan dampak dapat dilakukan dengan berbagai alternatif yaitu: pembuatan dinding laut dan tanggul, pemecah ombak, saluran penampung kenaikan air laut, regenerasi mangrove, relokasi penduduk dikawasan pantai. Pembuatan, tanggul, pemecah ombak dan saluran penampung kenaikan air laut memerlukan biaya cukup banyak sehingga diperlukan pemilihan lokasi yang benar-benar memerlukan. Setiap kebijakan dan strategi dalam pemanfaatan sumberdaya pantai harus berdasarkan kepada : (1) pemahaman yang baik tentang proses-proses alamiah (ekohidrologis) yang berlangsung di kawasan pantai yang sedang dikelola; (2) kondisi ekonomi, sosial dan budaya masyarakat; dan (3) kebutuhan saat ini dan yang akan datang terhadap barang dan (produk) dan jasa lingkungan pantai. Dengan demikian pengelolaan wilayah pantai akan memberikan manfaat bagi semua pihak baik masyarakat maupun industri pariwisata.

\section{DAFTAR KEPUSTAKAAN}

Completion Report for Padang Area FC Project (II), Vol 1 Main report \& Vol 4 Drawings, November 2001. Darlan, Yudi dkk. 2004. Kajian Terpadu Lingkungan dan Sumber Daya Mineral Pesisir Padang dan Sekitarnya - Sumatera Barat. Pusat Penelitian dan Pengembangan Geologi Kelautan: Bandung.

Departemen Pekerjaan Umum Kantor Wilayah Sumatera Barat. 1995. Pengendalian Banjir Kota Padang. Dinas PSDA Sumatera Barat. 1999. Pengendalian Banjir dan Penanggulangan Abrasi Kota Padang.

Gafoer, S. dkk. 1996. Peta Geologi Lembar Padang, Sumatera. Pusat Penelitian dan Pengembangan Geologi: Bandung. 